\title{
Penerapan Metode UEQ dan Cooperative Evaluation untuk Mengevaluasi User Experience Lapor Bantul
}

\author{
Implementation Methods of UEQ and Cooperative Evaluation \\ to Evaluate User Experience Lapor Bantul
}

\author{
Sewindu Putro*1, Kusrini' ${ }^{2}$, Mei P Kurniawan ${ }^{3}$ \\ 1,2,3 Magister Teknik Informatika Universitas Amikom Yogyakarta \\ E-mail: *1 sewindu7985@students.amikom.ac.id mail, ${ }^{2}$ kusrini@amikom.ac.id, \\ ${ }^{3}$ meikurniawan@amikom.ac.id
}

\begin{abstract}
Abstrak
Lapor Bantul adalah sebuah aplikasi yang dibuat oleh Pemerintah Kabupaten Bantul yang berfungsi untuk menangani segala permasalahan dan keluhan-keluhan di sekitar kabupaten Bantul. Berdasarkan seluruh data review dan rating dari pengguna Lapor Bantul yang sudah di dikumpulkan dan kemudian diklasifikasikan antara review positif dan negatif, mayoritas review yang diberikan pengguna berisi ungkapan kekecewaan dan keluhan terhadap aplikasi tersebut. Dalam penelitian ini metode yang akan digunakan adalah User Experience Questionnaire (UEQ) dengan menggunakan 6 skala pengukuran pengalaman pengguna dan metode evaluasi kooperatif untuk menentukan masalah yang dihadapi oleh pengguna saat menggunakan aplikasi Lapor Bantul. Tujuan evaluasi ini adalah mengukur pengalaman pengguna dan hasil rekomendasi user experience yang digunakan untuk membangun prototipe. Hasil pengukuran pengalaman pengguna aplikasi Lapor Bantul mengalami peningkatan dalam setiap skala kuesioner pengalaman pengguna, termasuk daya tarik dengan peningkatan 0,89, perspektif 1,23, efisiensi 0,63, keandalan 0,81, stimulasi 0,74 dan kebaruan 0,78. Kemudian, di benchmark UEQ perbandingan desain sebelum dievaluasi dan sesudah dievluasi juga mengalami peningkatan pengalaman pengguna, yang sebelumnya kategorikan dalam kategori below average (di bawah rata-rata) menjadi good (baik).
\end{abstract}

Kata Kunci - Lapor Bantul, User Experience, User Interface, UEQ, Cooperative Evaluation

\begin{abstract}
Abstrak Lapor Bantul is an application made by the district government of Bantul which functions to handle all problems and complaints around Bantul district. Based on all the review and rating data from Lapor Bantul users that has been collected and then classified between positive and negative reviews, the majority of reviews given by users contain expressions of disappointment and complaints about the application. In this study the method to be used is User Experience Questionnaire (UEQ) using 6 scales of user experience measurement and cooperative evaluation methods to determine the problems faced by users when using the application to Lapor Bantul. The purpose of this evaluation is to measure user experience and the user experience recommendations used to build prototypes. The results of measuring user experience in the Lapor Bantul experienced an increase in each scale of the user experience questionnaire, including attraction with an increase of 0.89 , perspective 1.23 , efficiency 0.63 , reliability 0.81 , stimulation 0.74 and novelty 0.78 . Then, in the UEQ benchmark the comparison of designs before being evaluated and after being evaluated also experienced an increase in user experience, which previously categorized the below average category to be good.
\end{abstract}

Keywords - Lapor Bantul, User Experience, User Interface, UEQ, Cooperative Evaluation 


\section{PENDAHULUAN}

Pada tahun 2009 pemerintah telah mengeluarkan UU No. 25 tentang pelayanan publik. Peraturan ini dikeluarkan bertujuan untuk untuk mengingatkan kewajiban negara dalam melayani warga negara untuk memenuhi hak dan kebutuhan dasarnya dalam tentang pelayanan publik. Untuk memberikan pelayanan publik yang lebih baik, diperlukan untuk memahami sikap dan perubahan kepentingan publik itu sendiri. Salah satu perkembangan yang terjadi didalam masyarakat adalah perkembangan teknologi informasi [1].

Untuk mengantisipasi perkembangan teknologi informasi pada masyarakat, pemerintah telah meluncurkan sistem e-government seperti yang sudah dilakukan oleh Pemerintah Kabupaten Bantul yang telah membuat aplikasi Lapor Bantul. Lapor Bantul adalah sebuah aplikasi pelayanan publik yang dibuat oleh Pemerintah Kabupaten Bantul yang berfungsi untuk menangani segala permasalahan dan keluhan-keluhan di sekitar kabupaten Bantul. Namun aplikasi ini masih dalam tahap uji coba. Berdasarkan hasil wawancara dengan pihak Lapor Bantul bahwa Pemerintah Kabupaten Bantul mulai melakukan penyebarluasan informasi melalui media cetak maupun media sosial dengan hadirnya aplikasi tersebut. Namun tindakan tersebut tidak sesuai dengan apa yang diharapkan karena dari jumlah total pengguna yang menginstal aplikasi tersebut masih belum mencapai target yang sudah ditentukan dan dari laporan akun google developer console, jumlah uninstal pengguna mengalami penurunan setiap harinya. Selain itu, berdasarkan seluruh data review dan rating dari pengguna Lapor Bantul yang sudah dikumpulkan dan kemudian diklasifikasikan antara review positif dan negatif, mayoritas review yang diberikan pengguna berisi ungkapan kekecewaan dan keluhan terhadap aplikasi tersebut. Pihak Lapor Bantul mengatakan bahwa aplikasi tersebut masih perlu ditingkatkan dan dioptimalkan dengan berkolaborasi dengan masayarakat.

Rating dan review adalah bentuk penilaian pengguna secara langsung yang sudah memiliki pengalaman dalam menggunakan aplikasi [2]. Sebuah aplikasi memiliki antarmuka yang berfungsi sebagai perantara antara pengguna dengan aplikasi agar bisa saling berinteraksi. Setiap aplikasi memiliki tampilan antarmuka yang berbeda - beda sesuai dengan kebutuhan dan fungsinya. Antarmuka sebuah aplikasi bertujuan untuk menjadikan sebuah aplikasi mudah digunakan oleh pengguna atau disebut dengan istilah user experience. Istilah user experience digunakan untuk menunjuk kepada kemampuan yang dimiliki sebuah aplikasi yang mudah dioperasikan, dan mempunyai sejumlah kemampuan lain sehingga pengguna merasa nyaman dalam meggunakan aplikasi tersebut. Namun kenyataannya masih ada aplikasi yang memiliki antarmuka yang kurang baik sehingga sulit dipahami oleh pengguna.

Menurut ISO 9241-210 tahun 2010, pengalaman pengguna adalah persepsi serta respons pengguna akibat dari penggunaan sebuah sistem, layanan, dan produk [3]. Menurut Norman, setiap hal yang mengenai pengguna dengan produk, sistem dan layanan yang saling berinteraksi adalah definisi lain dari pengalaman pengguna [4]. Dengan demikian, melalui interaksi pengguna dengan aplikasi Lapor Bantul, pengguna dapat memberikan persepsi tambahan tentang pemerintah Kabupaten Bantul sebagai organisasi layanan aplikasi Lapor Bantul. suatu layanan dapat memengaruhi citra organisasi atau penyedia.

Penelitian sebelumnya yang mengevaluasi dua aplikasi layanan pengaduan publik online, LAPOR! dan Qlue menggunakan tes kegunaan didukung oleh kuesioner USE dengan empat parameter: utilitas, kemudahan penggunaan, kemudahan belajar dan kepuasan. Penyusunan kerangka kerja untuk perbaikan dalam penelitian ini menggunakan Human Centered Design (HCD) [5]. Penelitian lain yang terkait dengan layanan penanganan pengaduan online yang mengevaluasi aplikasi situs Web E-Complaint Universitas Brawijaya menggunakan evaluasi heuristik dan penilaian usability menggunakan System Usability Scale (SUS) [6].

Selanjutnya penelitian yang dilakukan oleh Santoso yang mengavaluasi aplikasi web SinTA Universitas Kristen Duta Wacana menggunakan metode User Experience Questionnaire dengan memanfaatkan 6 skala yang ada kemudian rekomendasi desain yang diusulkan didapatkan dari saran pengguna yang sudah dikelompokkan berdasarkan skala User Experience Questionnarie [7]. 
Dalam penelitian yang dilakukan sebelumnya yang telah melakukan pengukuran tingkat user experience pada Universitas XYZ menggunakan metode User Experience Questionnarie. Selain dari data kuantitatif responden juga memberikan feedback terhadap aplikasi yang telah digunakan. Namun dari feedback tersebut peneliti tidak memberikan rekomendasi perbaikan desain yang diusulkan [8].

Berdasarkan pada uraian masalah dan literatur penelitian sebelumnya, penelitian yang dilakukan ini akan mengevaluasi aplikasi Lapor Bantul menggunakan metode User Experience Questionnaire (UEQ) dan untuk mendapatkan seluruh persepsi dan masalah yang dihadapi oleh pengguna, menggunakan Teknik Cooperative Evaluation. Kemudian, hasil evaluasi aplikasi lama akan didesain ulang dalam bentuk prototipe berdasarkan persepsi pengguna. Selanjutnya, desain perbaikan dalam bentuk prototipe akan dievaluasi kembali untuk menguji perbedaan tingkat pengalaman pengguna aplikasi yang lama dengan aplikasi baru berdasarkan konsep User Experience Questionnaire (UEQ). Alasan menggunakan metode UEQ karena kuisioner yang cepat dan mudah untuk mengukur pengalaman pengguna sebuah aplikasi, sedangkan memilih menggunakan Cooperative Evaluation karena teknik tersebut evaluator dapat melakukan diskusi dengan responden sehingga dapat memastikan lebih detail mengenai masalah apa saja yang dihadapai pengguna saat menggunakan aplikasi tersebut. Tujuan dari penelitian ini adalah mengukur dan memperbaiki User Experience aplikasi Lapor Bantul. Dengan harapan jika User Experience bagus maka pengguna akan betah menggunakan aplikasi, sehingga dapat membantu proses pembangunan Pemerintah Kabupaten Bantul.

\section{METODE PENELITIAN}

\subsection{Penentuan Populasi Sampel}

Sebelum peneliti melaksanakan kegiatan pengumpulan data, maka terlebih dahulu harus menentukan sumber data penelitian. Dalam penelitian ini, penentuan populasi dan sampel akan digunakan sebagai sumber data penelitian.

\subsection{Uji Validitas dan Uji Reliabilitas}

Uji Validitas dan reliabilitas digunakan untuk mengetahui kelayakan sebuah kuisioner. Kuisioner akan dikatakan layak jika valid dan reliabel. Uji validitas akan menggunakan metode korelasi produk momen dan uji reliabilitas akan menghitung nilai Cronbach’s Alpha

\subsection{Mengukur Desain Sebelum Dievaluasi Menggunakan Metode UEQ}

Pada langkah ini melakukan pengukuran pengalaman pengguna untuk mengetahui tingkat pengalaman pengguna dari desain aplikasi Lapor Bantul. UEQ memiliki banyak manfaat, salah satunya adalah untuk membandingkan level pengalaman pengguna dari 2 buah produk, untuk pengujian pengalaman pengguna sebuah produk dan untuk peningkatan pada area tertentu [9]. Pertanyaan yang ada pada kuisioner UEQ ini memiliki perbedaan dengan kuisioner yang lain, kuisioner pada metode UEQ ini dibagi menjadi 6 skala evaluasi pengukuran dan 26 item pertanyaan, yaitu:

1. Daya tarik: daya tarik suatu produk dalam persepsi keseluruhannya.

2. Perspicuity: kemudahan penggunaan suatu produk.

3. Efisiensi: kecepatan pengguna menyelesaikan tugas.

4. Keandalan: Dapatkah interaksi dikontrol oleh pengguna?

5. Stimulasi: sejauh mana pengguna termotivasi untuk menggunakan produk.

6. Kebaruan: inovasi pada sebuah sistem, layanan dan produk. 
Susunan skala UEQ yang digunakan untuk mengukur pengalaman pengguna ditunjukkan pada Gambar 1.

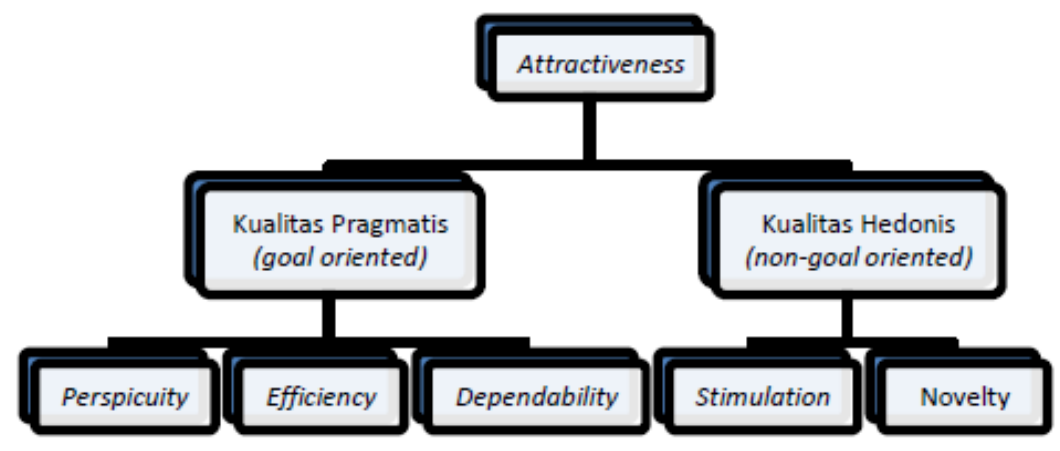

Gambar 1. Susunan Skala UEQ (Schrepp, 2014)

\subsection{Mengumpulkan Presepsi dan Masalah Menggunakan Cooperative Evaluation}

Cooperative Evaluation adalah prosedur untuk memperoleh data tentang masalah berpengalaman saat bekerja dengan produk perangkat lunak, sehingga perubahan bisa terjadi dibuat untuk meningkatkan produk [10]. Pada tahap ini evaluator mendiskusikan kepada pengguna aplikasi mengenai masalah apa saja yang dialami pengguna aplikasi Lapor Bantul. Responden yang diambil sebanyak 5 pengguna yang paling sering menggunakan aplikasi Lapor Bantul.

\subsection{Menganalisis Hasil Desain Sebelum Dievaluasi}

Pada tahap ini melakukan analisis hasil pengukuran pengalaman pengguna desain sebelum dievaluasi dari 30 responden data UEQ yang sudah dikumpulkan, selanjutnya dari hasil pengukuran akan divisualisaikan dalam bentuk diagram. Hasil dari Cooperative Evaluation disajikan dalam bentuk tabel yang berisi uraian berupa persepsi dan masalah yang dihadapi oleh pengguna saat menggunakan aplikasi Lapor Bantul serta rekomendasi dari masing-masing pengguna.

\subsection{Membuat Rekomendasi Desain}

Pembuatan rekomendasi desain berdasarkan dari hasil evaluasi dengan pengguna menggunakan teknik Cooperative Evaluation yang sudah dilakukan sebelumnya. Rekomendasi desain berupa sebuah prototype yang dikelompokkan berdasarkan setiap menu aplikasi Lapor Bantul.

\subsection{Pengukuran Desain Baru Menggunakan UEQ}

Setelah rekomendasi desain selesai, pengujian ulang dilakukan dengan 30 responden menggnakan UEQ untuk membandingkan hasil tingkat pengalaman pengguna dari Laporan aplikasi Bantul sebelum dilakukanan evaluasi dan setelah evaluasi.

\subsection{Penjelasan Dari Hasil Perbandingan Desain Sebelum Dievaluasi dan Sesudah}

Pada tahap ini dilakukan perbandiangan hasil evaluasi desain sebelum dievaluasi dan sesudah. Perbandiangan dari hasil evaluasi akan di visualisaikan dalam bentuk diagram benchmark UEQ, tingkat user experience pada setiap skala UEQ. Kemudian dari hasil evaluasi perbandingan dari kedua versi aplikasi Lapor Bantul akan diuraikan secara deskriptif. 
Citec Journal, Vol. 6, No. 1, Februari 2019

ISSN: 2460-4259

\subsection{Penarikan Kesimpulan dan Saran}

Setelah seluruh tahap evaluasi selesai kemudian melakukan penarikan kesimpulan dan memberikan saran untuk penelitian selanjutnya.

\section{HASIL DAN PEMBAHASAN}

\subsection{Populasi dan Sampel}

Jumlah sampel ditetapkan berdasarkan pada (Schrepp, 2015) bahwa sebuah sistem, produk dan layanan yang serupa dievaluasi dengan bantuan User Experience Questionnaire, dengan responden 20 sampai dengan 30 menghasilkan yang cukup stabil, sehingga jumlah responden akan memenuhi persyaratan User Experience Questionnaire yang diharapkan [9]. Maka populasi dalam penelitian ini adalah seluruh pengguna aktif aplikasi Lapor Bantul. Kemudian sampel yang digunakan yaitu 30 pengguna aktif aplikasi Lapor Bantul.

\subsection{Hasil Uji Validitas dan Uji Reliabilitas}

Validitas sebuah instrumen penelitian diketahui dengan mengkorelasikan setiap masingmasing total skor pertanyaan. Korelasi dinyatakan valid jika memiliki nilai correlation rhitung > rtabel. Nilai rtabel bergantung pada jumlah responden yang dapat dilihat dari tabel r standar pada tabel statistik. Pada penelitian ini, uji validitas menggunakan 30 responden dengan tingkat kepercayaan 5\% sehingga rtabel harus lebih besar dari 0.361. Metode yang digunakan untuk uji validitas adalah correlate bivariate pearson (korelasi produk momen). Pengujian dilakukan dengan menggunkan bantuan software SPSS. Hasil uji validitas dapat dilihat pada Tabel 1.

Tabel 1. Hasil Uji Validitas

\begin{tabular}{|l|l|l|l|l|l|l|l|}
\hline Item & $\mathbf{r}_{\text {hitung }}$ & $\mathbf{r}_{\text {tabel }}$ & Keterangan & Item & $\mathbf{r}_{\text {hitung }}$ & $\mathbf{r}_{\text {tabel }}$ & Keterangan \\
\hline 1 & 0.604 & 0.361 & Valid & 14 & 0.410 & 0.361 & Valid \\
\hline 2 & 0.566 & 0.361 & Valid & 15 & 0.739 & 0.361 & Valid \\
\hline 3 & 0.645 & 0.361 & Valid & 16 & 0.525 & 0.361 & Valid \\
\hline 4 & 0.700 & 0.361 & Valid & 17 & 0.738 & 0.361 & Valid \\
\hline 5 & 0.608 & 0.361 & Valid & 18 & 0.660 & 0.361 & Valid \\
\hline 6 & 0.607 & 0.361 & Valid & 19 & 0.739 & 0.361 & Valid \\
\hline 7 & 0.706 & 0.361 & Valid & 20 & 0.777 & 0.361 & Valid \\
\hline 8 & 0.498 & 0.361 & Valid & 21 & 0.707 & 0.361 & Valid \\
\hline 9 & 0.740 & 0.361 & Valid & 22 & 0.784 & 0.361 & Valid \\
\hline 0 & 0.581 & 0.361 & Valid & 23 & 0.867 & 0.361 & Valid \\
\hline 11 & 0.616 & 0.361 & Valid & 24 & 0.816 & 0.361 & Valid \\
\hline 12 & 0.534 & 0.361 & Valid & 25 & 0.682 & 0.361 & Valid \\
\hline 13 & 0.630 & 0.361 & Valid & 26 & 0.642 & 0.361 & Valid \\
\hline
\end{tabular}

Uji reliabilitas dilakukan untuk mengetahui konsistensi alat ukur dan apakah alat ukur tersebut dapat diandalkan dan tetap konsisten saat dilakukan pengukuran secara berulang. Selain itu, uji ini digunakan untuk mengetahui apakah jawaban responden dapat digunakan pada tahap selanjutnya. Kesepakatan secara umum reliabilitas yang dianggap sudah cukup memuaskan jika $\geq 0.700$. Uji reliabilitas dilakukan dengan menghitung nilai koefisien Cronbach's alpha dengan menggunakan bantuan software SPSS. Hasil reliabilitas dapat dilihat pada Tabel 2.

Tabel 2. Hasil Uji Reliabilitas

\begin{tabular}{|r|r|}
\hline Cronbach's Alpha & N of Items \\
\hline .954 & 26 \\
\hline
\end{tabular}


Berdasarkan hasil nilai koefisien Cronbach's alpha 0.954 bahwa ke - 26 item peryataan dinyatakan reliabel.

\subsection{Hasil Pengukuran UEQ Desain Sebelum Dievaluasi}

Tahapan yang dilakukan setelah mendapatkan hasil kuisioner dari responden adalah mengolah data. Data akan diolah dengan metode UEQ dengan menggunakan bantuan Data Analysis Tools yang di download dari situs resmi https://www.ueq-online.org. Hasil evaluasi ratarata skala User Experience Questionnaire untuk aplikasi Lapor Bantul dapat dilihat pada Tabel 3 dan Gambar 2.

Tabel 3. Hasil Pengukuran Desain Sebelum Dievaluasi

\begin{tabular}{|c|c|}
\hline Skala & Rata-Rata \\
\hline Attractiveness & 0.79 \\
\hline Perspicuity & 0.69 \\
\hline Efficiency & 1.13 \\
\hline Dependability & 0.79 \\
\hline Stimulation & 0.58 \\
\hline Novelty & 0.32 \\
\hline
\end{tabular}

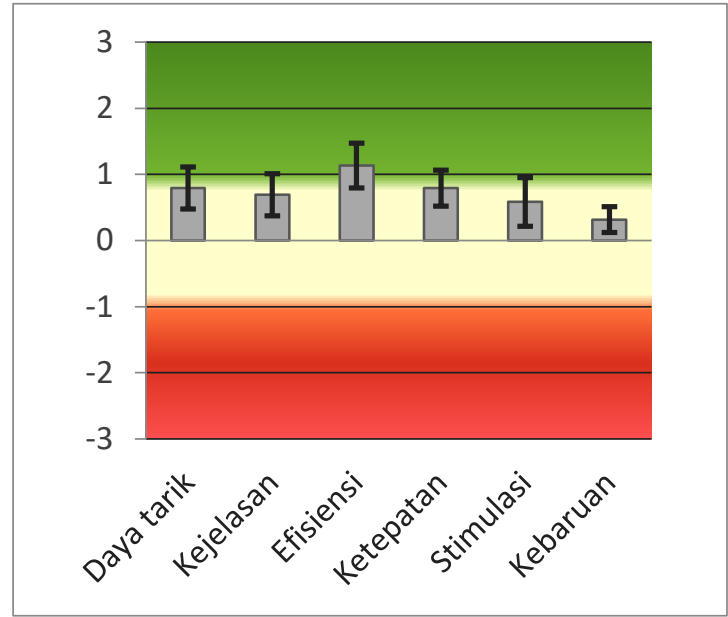

Gambar 2. Grafik Hasil Pengukuran Desain Sebelum Dievaluasi

Dari hasil evaluasi dapat dilihat bahwa rata - rata skala total tidak mencapai di angka 1 dengan nilai tertinggi pada skala efisiensi sebesar 1.13 dan nilai terendah pada skala kebaruan dengan nilai sebesar 0.32. Kemudian dari data rata - rata setiap skala selanjutnya data diolah dan menghasilkan diagram benchmark pada Gambar 3.

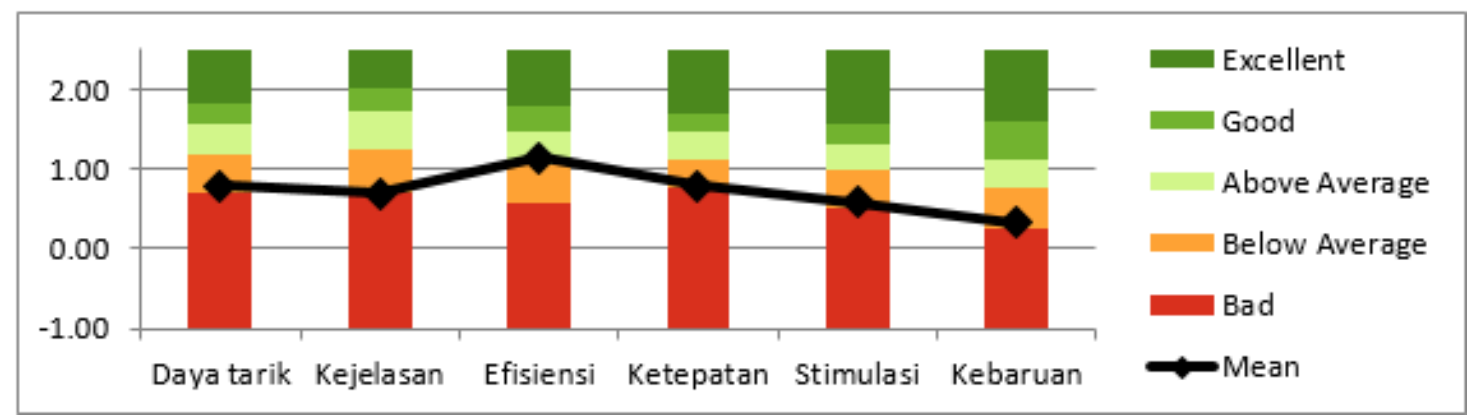

Gambar 3. Diagram Benchmark UEQ Desain Sebelum Dievaluasi 
Berdasarkan diagram benchmark desain lama aplikasi Lapor Bantul dapat dikatakan dalam kategori Below Average (dibawah rata-rata) karena dari setiap skala meliliki nilai rata-rata total di bawah 1, sehingga selanjutnya akan dilakukan evaluasi menggunakan teknik Cooperative Evaluation untuk mengetahui masalah apa saja yang dihadapai sesuai dengan presepsi pengguna.

\subsection{Cooperative Evaluation}

Sebelum melakukan evaluasi ini tahap awal yang dilakukan adalah menentukan partisipan. Sesuai aturan yang sudah ditetapkan untuk melakukan evaluasi ini dibutuhkan 2 sampai dengan 5 partisipan [10]. Partisipan yang diambil adalah responden yang sering menggunakan aplikasi Lapor Bantul sebanyak 5 orang dari 30 responden yang sudah ditentukan sebelumnya. Kemudian tahap selanjutnya evaluator meminta pengguna untuk menjalakan seluruh fitur yang ada pada aplikasi Lapor Bantul. Kemudian setelah seluruh fitur sudah selesai dijalankan, evaluator melakukan diskusi dengan pengguna pada setiap fitur yang sudah dijalankan, dan menanyakan masalah apa saja yang dihadapai pengguna ketika menggunakan aplikasi Lapor Bantul serta menanyakan rekomendasi apa yang dapat diberikan. Setiap pernyataan-pernyataan partisipan dihubungkan dengan skala UEQ. Hasil evaluasi dapat dilihat pada Tabel 4.

Tabel 4. Hasil Evaluasi Menggunakan Teknik Cooperativ Evaluation

\begin{tabular}{|l|l|l|}
\hline \multicolumn{1}{|c|}{ Presepsi } & \multicolumn{1}{|c|}{$\begin{array}{c}\text { Rekomendasi Yang } \\
\text { Diusulkan }\end{array}$} & \multicolumn{1}{c|}{ Alasan } \\
\hline $\begin{array}{l}\text { Bahasa dalam aplikasi } \\
\text { Lapor Bantul tidak } \\
\text { konsisten }\end{array}$ & $\begin{array}{l}\text { Perlu adanya konsistensi } \\
\text { bahasa }\end{array}$ & $\begin{array}{l}\text { Mencegah pengguna mengalami } \\
\text { kebingungan karena bahasa yang } \\
\text { tidak konsisten }\end{array}$ \\
\hline $\begin{array}{l}\text { Tidak terdapat keterangan } \\
\text { pada setiap menu }\end{array}$ & $\begin{array}{l}\text { Perlu adanya keterangan } \\
\text { pada setiap menu yang ada }\end{array}$ & $\begin{array}{l}\text { Untuk mempermudah pengguna } \\
\text { dalam mengingat fitur yang } \\
\text { terdapat pada aplikasi }\end{array}$ \\
\hline $\begin{array}{l}\text { Aplikasi tidak } \\
\text { memberikan untuk } \\
\text { membatalkan perintah } \\
\text { jika pengguna melakukan } \\
\text { kesalahan input data }\end{array}$ & $\begin{array}{l}\text { Perlu adanya peringatan } \\
\text { ketika pengguna } \\
\text { mengalami kesalahan } \\
\text { dalam penginputan data }\end{array}$ & $\begin{array}{l}\text { Untuk memneritahu kepada } \\
\text { pengguna bahwa aksi yang } \\
\text { dilakukan harus dibatalkan atau di } \\
\text { perbaiki }\end{array}$ \\
\hline $\begin{array}{l}\text { Tidak tersedia menu edit } \\
\text { komentar }\end{array}$ & $\begin{array}{l}\text { Perlu adanya navigasi } \\
\text { hapus, update dan edit data. }\end{array}$ & $\begin{array}{l}\text { Untuk mengupdate data yang } \\
\text { salah ketika proses input data }\end{array}$ \\
\hline $\begin{array}{l}\text { Icon menu pada kategori } \\
\text { dan sub kategori kurang } \\
\text { menarik }\end{array}$ & $\begin{array}{l}\text { Icon yang ada harus } \\
\text { disesuaikan dengan nama } \\
\text { kategori dan sub kategori }\end{array}$ & $\begin{array}{l}\text { Mempermudah dan mencegah } \\
\text { pengguna kebingungan dalam } \\
\text { memilih kategori sesuai yang } \\
\text { diinginkan }\end{array}$ \\
\hline $\begin{array}{l}\text { Petunjuk penggunaan } \\
\text { aplikasi kurang jelas }\end{array}$ & $\begin{array}{l}\text { Menambahkan gambar atau } \\
\text { video pada setiap langkah }\end{array}$ & $\begin{array}{l}\text { Untuk mempermudah pengguna } \\
\text { baru dalam memahami } \\
\text { penggunaan aplikasi }\end{array}$ \\
\hline $\begin{array}{l}\text { Aplikasi tidak } \\
\text { memberikan umpan balik } \\
\text { pada beberapa aksi }\end{array}$ & $\begin{array}{l}\text { Diperlukan adanya umpan } \\
\text { balik pada setiap aksi }\end{array}$ & $\begin{array}{l}\text { Untuk memberitahu pengguna } \\
\text { bahwa proses telah selesai }\end{array}$ \\
\hline
\end{tabular}

\subsection{Perancangan Desain Perbaikan Aplikasi Lapor Bantul}

Rancangan rekomendasi desain user interface dilakukan berdasarkan dari hasil evaluasi Cooperative berupa desain mockup setiap halaman yang ada pada aplikasi Lapor Bantul. Desain user interface akan ditampilan perbandiangan desain lama dengan desain baru. Sesuai rekomendasi yang diberikan berdasarkan dari hasil evaluasi Cooperative, terdapat masalah pada setiap menu tidak terdapat keterangan serta pada menu pilihan dikategori kurang menarik karena 
seluruh icon kategori memiliki gambar yang sama. Perbandingan tampilan user interface yang lama dan baru dapat dilihat pada Gambar 4.

Desain Lama
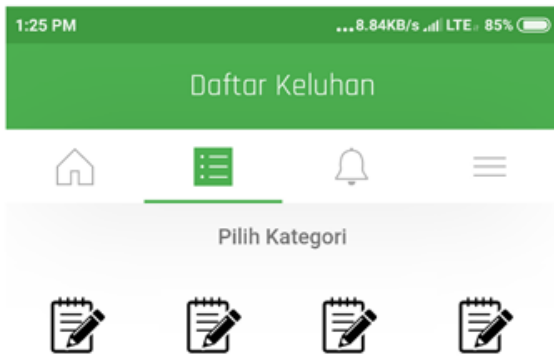

Air Bersih

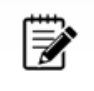

Ekonomi

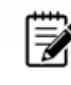

Infrastruktur
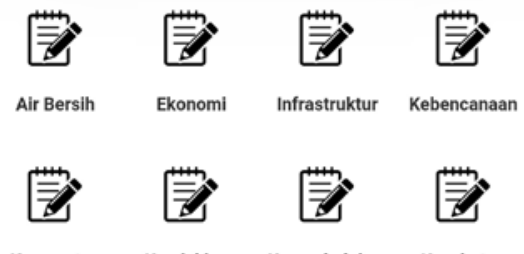

Kecamatan

Kemiskinan

Kependudukan

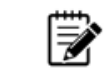

Ketenagakerjaa
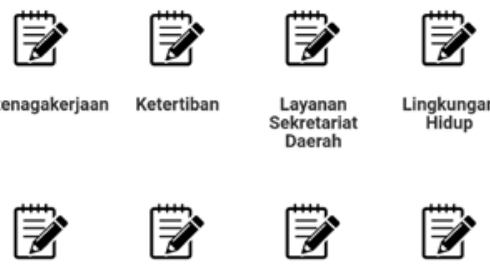

Olah Raga
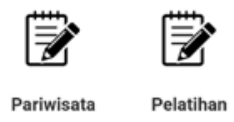

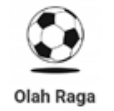

\section{Desain Baru}
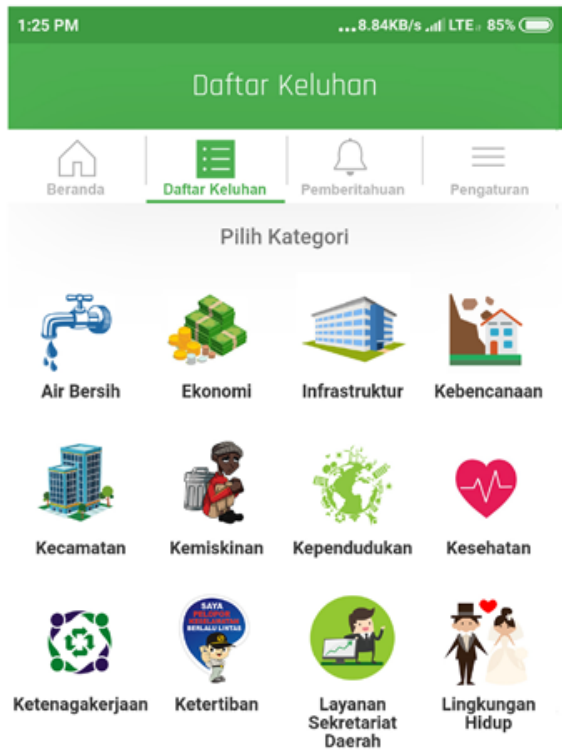

Gambar 4. Perbandingan Tampilan Desain Lama dan Baru Pada Menu Kategori

Sedangakan untuk halaman pengaturan terdapat menu yang menggunakan 2 bahasa, artinya pada menu pengaturan terdapat masalah mengenai bahasa yang tidak konsisten dengan alasan akan mengalami kebingungan karena bahasa yang tidak konsisten. Perbandingan tampilan user interface pada menu pengaturan yang lama dan baru dapat dilihat pada Gambar 5.

Desain Lama
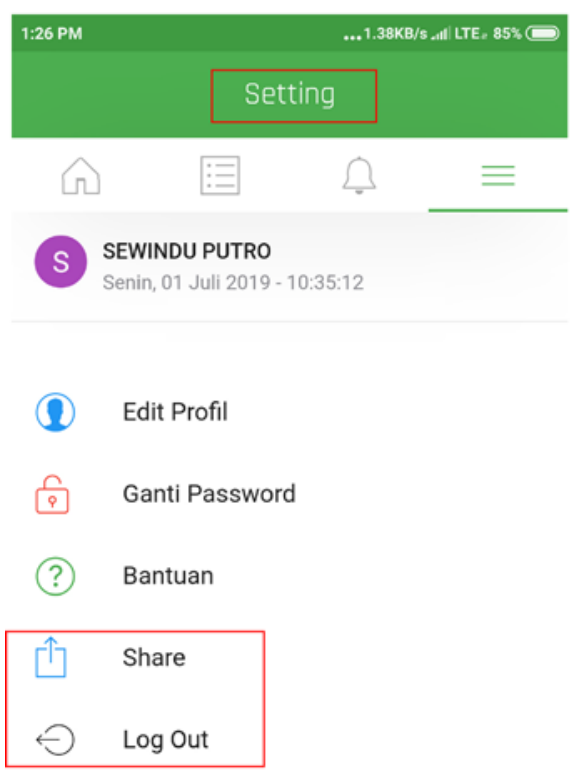

Desain Baru

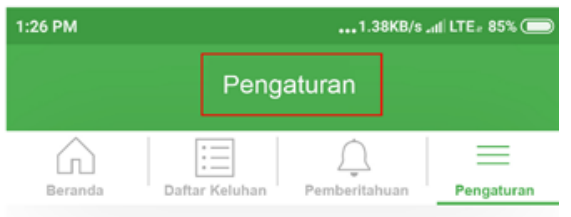

(S) SEWINDU PUTRO

Senin, 01 Juli 2019 - 10:35:12

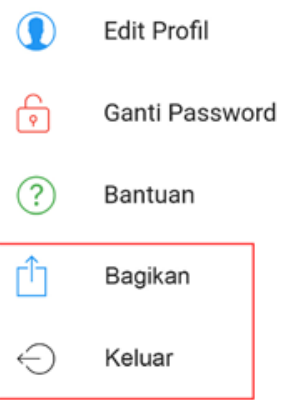

Gambar 5. Perbandingan Tampilan Desain Lama dan Baru Pada Menu Pengaturan 
Citec Journal, Vol. 6, No. 1, Februari 2019

\subsection{Hasil Pengukuran User Experience Questionnaire Rekomendasi Desain}

Hasil Pengukuran rekomendasi desain baru menggunakan UEQ dipaparkan pada grafik Gambar 6 beserta perbandingannya pada grafik Gambar 7.

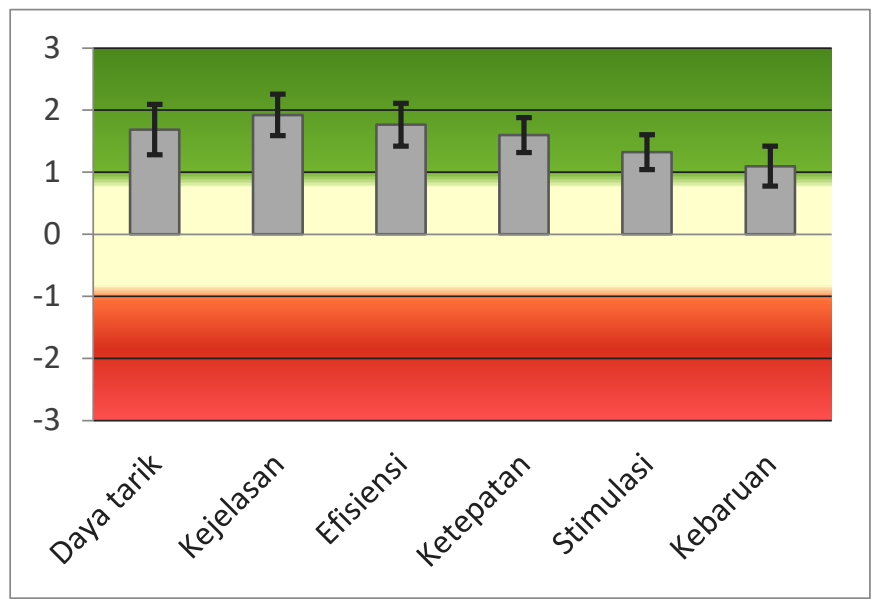

Gambar 6. Grafik Hasil Pengukuran Desain Sesudah Dievaluasi

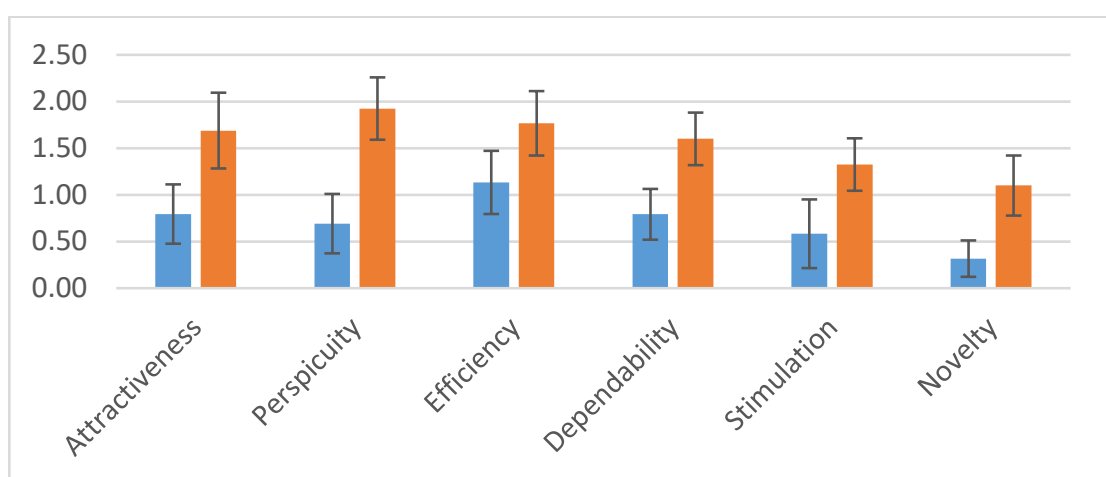

Gambar 7. Perbandingan Hasil Desain Sebelum Dievaluasi dan Sesudah

Perbedaan rata-rata antara setiap skala UEQ desain sebelum dievalusai dan sesudah mengalami perubahan dan memiliki peningkatan pada setiap skala. Rata-rata setiap evaluasi UEQ dalam desain lama dan baru dapat dilihat pada Tabel 5 di bawah ini.

Tabel 5. Perbandingan Hasil Pengukuran Desain Sebelum Dievaluasi dan Sesudah

\begin{tabular}{|l|c|c|c|}
\hline \multicolumn{1}{|c|}{ Skala } & Desain Sebelum Dievaluasi & Desain Sesudah Dievaluasi & Peningkatan \\
\hline Attractiveness & 0.79 & 1.69 & 0.89 \\
\hline Perspicuity & 0.69 & 1.93 & 1.23 \\
\hline Efficiency & 1.13 & 1.77 & 0.63 \\
\hline Dependability & 0.79 & 1.60 & 0.81 \\
\hline Stimulation & 0.58 & 1.33 & 0.74 \\
\hline Novelty & 0.32 & 1.10 & 0.78 \\
\hline
\end{tabular}

Untuk skala daya tarik mengalami peningkatan sebesar 0,89, kejelasan 1,23, efisiensi 0,63, keandalan 0,81, stimulasi 0,74 dan kebaruan 0,78. Kemudian untuk menentukan apakah desain baru aplikasi Lapor Bantul memberikan tingkat pengalaman pengguna yang cukup dilakukan uji benchmark. Hasil pengukuran benchmark User Experience Questionnaire (UEQ) disajikan dalam diagram pada Gambar 7. 


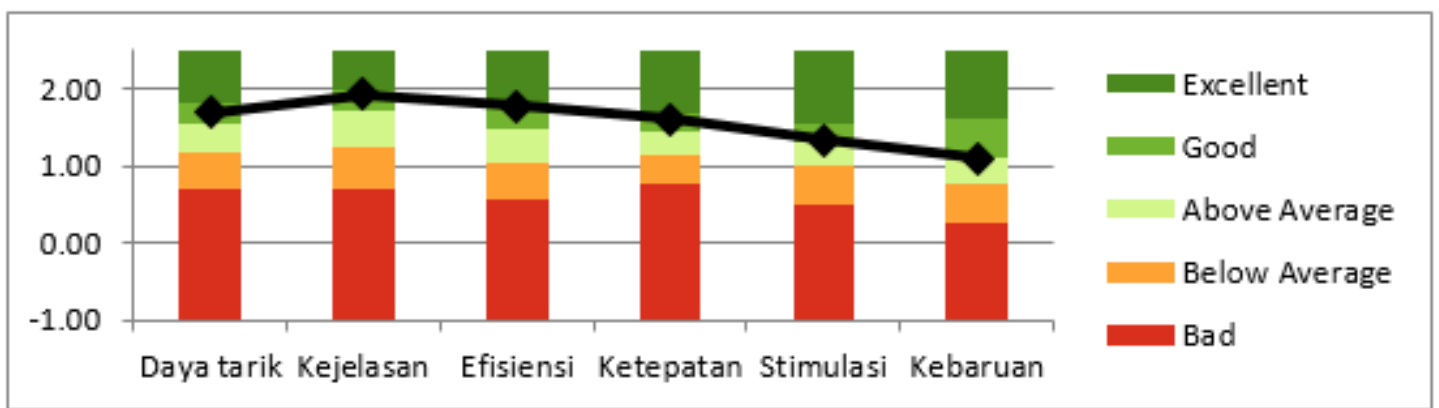

Gambar 7. Diagram benchmark UEQ Desain Sesudah Dievaluasi

Berdasarkan gambar dari grafik hasil benchmark, lima skala masuk dalam kategori yang bagus, yaitu skala daya tarik, efisiensi, akurasi, stimulasi dan kebaruan. Sedangkan skala kejelasan berada dalam kategori Sangat Baik sesuai dengan tingkatan benchmark UEQ yang sudah ditentukan.

\section{KESIMPULAN}

Berdasarkan dari hasil evaluasi, dapat disimpulkan bahwa:

1. Hasil pengukuran tingkat pengalaman pengguna desain baru mengalami peningkatan ratarata dalam setiap skala UEQ, termasuk daya tarik dengan peningkatan sebesar 0,89 , kejelasan 1,23, efisiensi 0,63, keandalan 0,81, stimulasi 0,74 dan kebaruan 0,78

2. Benchmark UEQ tingkat pengalaman pengguna dari desain baru aplikasi Lapor Bantul meningkat dengan semua skala yang sebelumnya dikategorikan dalam kategori Below Average (di bawah rata-rata) naik menjadi Good (Baik) dan pada semua skala peningkatan terbesar yaitu pada skala kejelasan. Kategori yang baik pada skala daya tarik, efisiensi, ketepatan, stimulasi, dan kebaruan.

\section{SARAN} berikut:

Berdasarkan dari hasil penelitian yang sudah diperoleh maka ada beberapa saran sebagai

1. Bagi Developer aplikasi Lapor Bantul dapat memperbaiki beberapa hal diantaranya konsistensi pada serta penggunaan shortcut perlu diperjelas agar mudah dipahami oleh

2. Peneliti selanjutnya disarankan agar menggunakan metode evaluasi yang berbeda sehingga penelitian tersebut dapat membandingkan antara metode yang saat ini penelti gunakan dengan metode peneliti selanjutnya.

3. Penelitian ini hanya mengevaluasi dari sisi pengguna, kedepannya disarankan penelitian yang menggabungkan evaluasi dari sisi pengguna dan admin dari aplikasi Lapor Bantul.

\section{DAFTAR PUSTAKA}

[1] Saefullah, H.A., Djaja, 2008, Pemikiran Kontemporer Administrasi Publik Perspektif Manajemen Sumber Daya Manusia dalam Era Desentralisasi, AIPI dan PK2W Lemlit Unpad, Bandung.

[2] Garrett, J.J., 2011, The Elements of User Experience: User-Centered Design for the Web and Beyond, Ed. 2, New Riders, United State of America. 
Citec Journal, Vol. 6, No. 1, Februari 2019

[3] ISO 9241, 2010, User Experience Glossary, https://www.iso.org/obp/ui/\#iso:std:iso:9241:210:ed-1:v1:en, diakses pada 30 Juni 2019.

[4] Norman, D., 2016, The Definition of User Experience (UX), www.nngroup.com.

[5] Azis, M. A., Az-Zahra, H.M., Fanani, L., 2019, Evaluasi dan Perancangan User Interface Aplikasi Mobile Layanan Pengaduan Masyarakat Online Menggunakan Human-Centered Design, Jurnal Pengembangan Teknologi Informasi dan Ilmu Komputer, No. 1, Vol. 3, Hal 529-537.

[6] Wibowo, W. S., Az-Zahra, H. M., Bachtiar, F.A., 2018, Evaluasi dan Rekomendasi Tampilan Website E-Complaint Universitas Brawijaya Pada Perangkat Bergerak Menggunakan Metode Heuristic Evaluation, Jurnal Pengembangan Teknologi Informasi dan Ilmu Komputer, No. 12, Vol. 2, Hal 7192-7201

[7] Santoso, N.A., Virginia, G., Susanto, B., 2017, Evaluation Interface Design to Build User Experience on SInTA Service Christian Duta Wacana University Yogyakarta, Transmormatika, No. 1, Vol. 15, Hal 26 - 35.

[8] Wulandari, I. R., Farida, D. L., 2018, Pengukuran User Experience Pada E-Learning Di Lingkungan Universitas Menggunakan User Experience Questionnare (UEQ), Jurnal Mantik Penusa, No. 2, Vol. 2, Hal 146 - 145.

[9] Schrepp, M., 2015, User Experience Questionnaire Handbook, Germany.

[10] Monk, A., Wright, P., Haber, J., Davenport, L., 1993, Improving Your Human-Computer Interface, Prentice-Hall, A Practical Technique (Bcs Practitioner). 